\title{
Energy, economy and exergy evaluations of the solutions for supplying domestic hot water from low-temperature district heating in Denmark
}

\author{
Yang, Xiaochen; Li, Hongwei; Svendsen, Svend
}

Published in:

Energy Conversion and Management

Link to article, DOI:

10.1016/j.enconman.2016.05.057

Publication date:

2016

Document Version

Peer reviewed version

Link back to DTU Orbit

Citation (APA):

Yang, X., Li, H., \& Svendsen, S. (2016). Energy, economy and exergy evaluations of the solutions for supplying domestic hot water from low-temperature district heating in Denmark. Energy Conversion and Management, 122, 142-152. https://doi.org/10.1016/i.enconman.2016.05.057

\section{General rights}

Copyright and moral rights for the publications made accessible in the public portal are retained by the authors and/or other copyright owners and it is a condition of accessing publications that users recognise and abide by the legal requirements associated with these rights.

- Users may download and print one copy of any publication from the public portal for the purpose of private study or research.

- You may not further distribute the material or use it for any profit-making activity or commercial gain

- You may freely distribute the URL identifying the publication in the public portal 


\section{Energy, economy and exergy evaluations of the solutions 2 for supplying domestic hot water from low-temperature 3 district heating in Denmark}

\section{Abstract}

12 District heating in Denmark is going through the transition from $3^{\text {rd }}$ generation

$13\left(80 / 40{ }^{\circ} \mathrm{C}\right)$ to $4^{\text {th }}$ generation $\left(50-55^{\circ} \mathrm{C} / 25^{\circ} \mathrm{C}\right)$ systems in preparation for district heating

14 based completely on renewable fuels by 2035. However, concern about Legionella

15 growth and reduced comfort with low-temperature domestic hot water supply may be

16 discouraging the implementation of low-temperature district heating. Aimed at

17 providing possible solutions, this study modelled various proposals for district heating

18 systems with supply temperatures of $65^{\circ} \mathrm{C}, 50^{\circ} \mathrm{C}$ and $35^{\circ} \mathrm{C}$ and for two different

19 building topologies. Evaluation models were built to investigate the energy, economy

20 and exergy performances of the proposed domestic hot water systems in various

21 configurations. The configurations of the devised domestic hot water substations were

22 optimized to fit well with both low and ultra-low-temperature district heating and to

23 reduce the return temperature to district heating. The benefits of lower return

24 temperatures were also analysed compared with the current district heating situation. 
25 The evaluation results show that the decentralized substation system with

26 instantaneous heat exchanger unit performed better under the $65^{\circ} \mathrm{C}$ and $50{ }^{\circ} \mathrm{C}$ district

27 heating scenarios, while the individual micro tank solution consumed less energy and

28 cost less in the $35^{\circ} \mathrm{C}$ district heating scenario.

\section{Keywords}

30 Low-temperature district heating, domestic hot water, Legionella, comfort, evaluation

31 model, low return temperature

\section{Highlights}

33 - Provided domestic hot water configurations for low-temperature district heating.

34 - Various building typologies and district heating supply temperatures were included.

35 - Different scenarios were evaluated from the energy, economy and exergy aspects.

36 - The benefits of lower return temperature to district heating were investigated.

\section{1. Introduction}

38 District heating $(\mathrm{DH})$ is of great importance for the sustainable energy system of the

39 future. In the district heating system, the heat is generated at the heat plant and

40 delivered to the substation by transmission network. In Denmark, most district heating

41 substations are designed and dimensioned to the served buildings. But area substation

42 and flat substation also exist for specific needs. Ultimately, the heat is supplied to the

43 consumer by the distribution network. The schematic of the common conventional

44 district heating system is shown in Fig. 1 


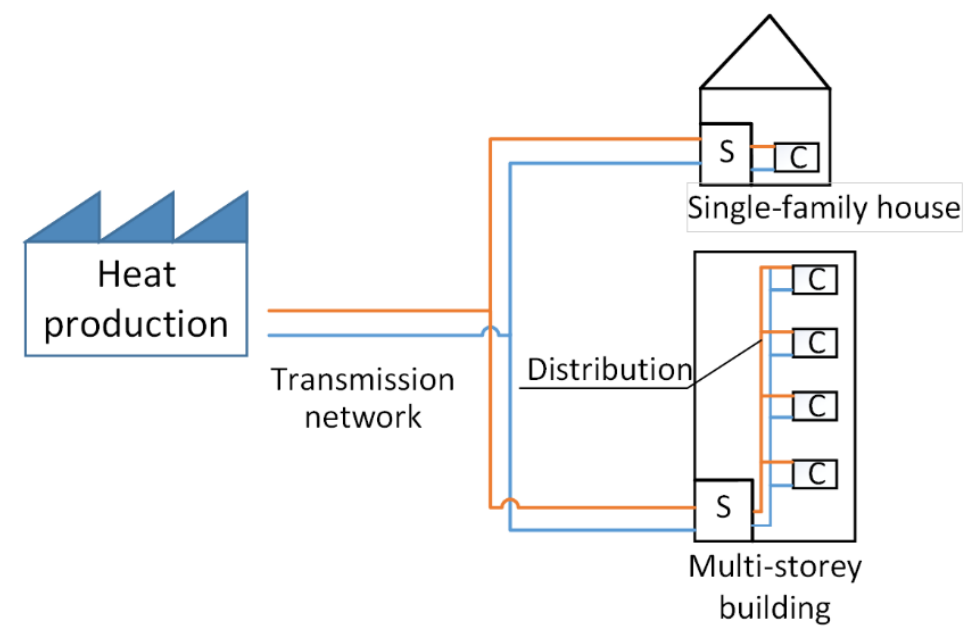

Fig. 1 Schematic of conventional district heating system

49 In most European countries including Denmark, the heat supply convers the demand of

50 both space heating and domestic hot water (DHW). To make the utmost use of

51 industrial excess heat and renewable energy sources, as well as to improve the

52 efficiency of the DH system, Danish district heating is undergoing the transition from the

53 current $3^{\text {rd }}$ generation district heating $\left(80 / 40{ }^{\circ} \mathrm{C}\right)$ to $4^{\text {th }}$ generation district heating

$54\left(55 / 25^{\circ} \mathrm{C}\right)$ without violating any comfort or hygiene requirements[1]. Moreover, the

55 savings from a more efficient heating system can results in more significant benefits in

56 the entire energy system by synergy effect with the electricity system, gas system and

57 etc.[2]. For heat supply to energy-efficient buildings in low heat density areas, it will be

58 even possible to apply the ultra-low-temperature district heating (ULTDH) with supply

59 temperature at $35-45^{\circ} \mathrm{C}$ to make the utmost use of the low-temperature excessive heat,

60 and improve the efficiency of the heat pump as heat production. 
61 The demand for domestic hot water (DHW), an important part of the total heat

62 demand, will play a yet bigger role in the energy-efficient buildings of the future. Over

63 the past 20 years, personal consumption of DHW has increased almost $50 \%$ [3], and, to

64 prevent Legionella, the DH supply for DHW preparation is always operated at high

65 temperatures. This leads to even larger energy consumption for DHW supply and more

66 heat loss during transmission and distribution. Therefore, to improve the efficiency of

67 the DH system, suitable solutions of supplying domestic hot water from low-

68 temperature district heating are in need.

\section{$69 \quad 1.1$ Comfort and hygiene requirements for domestic hot water supply}

70 With careful design and operation, space heating can work properly at low DH supply

71 temperature without supplementary heating. DHW production from LTDH, however,

72 requires more attention, because of the hygiene and comfort requirements which can

73 differ in different situations. According to the building regulations in Denmark, the

74 temperature requirements for DHW comfort and hygiene vary depending on the size of

75 the heating system. For systems with large DHW volumes, a high temperature regime is

76 required to inhibit Legionella, while the temperature requirements for systems with no

77 DHW storage or circulation are less strict. The specific comfort and hygiene

78 requirements for DHW temperatures are summarized in the Table 1, in which both

79 Danish and EU standards are taken into account [4].

80 Table 1 Temperatures required for hygiene and comfort in different building typologies

$\begin{array}{ll}\text { Systems with no } & \text { System with large DHW } \\ \text { circulation or storage tank } & \text { volume }\end{array}$




\begin{tabular}{lll}
\hline $\begin{array}{l}\text { Requirements for } \\
\text { Legionella prevention }\end{array}$ & - & $\begin{array}{l}\text { Storage tank } 60{ }^{\circ} \mathrm{C}, \\
\text { Circulation pipes }>50{ }^{\circ} \mathrm{C}\end{array}$ \\
\hline \multirow{2}{*}{ Requirements for comfort } & $45^{\circ} \mathrm{C}$ for kitchen use, & $45^{\circ} \mathrm{C}$ for for kitchen use, \\
& Waiting time $<10 \mathrm{~s}$ & $40{ }^{\circ} \mathrm{C}$ for other uses \\
& Waiting time $<10 \mathrm{~s}$ \\
\hline
\end{tabular}

821.2 Existing DHW system configuration with medium-temperature district heating

83 The conventional DHW system for medium-temperature district heating (MTDH) can be

84 different in single-family houses and multi-storey buildings. Both building topologies can

85 have small or large DHW volume depending on their substation configurations.

86 1.2.1 Conventional DHW configurations in single-family houses

87 Usually, DHW circulation is unnecessary for the single-family house to guarantee the

88 acceptable (10s) waiting time, since the distribution pipe length from the substation to

89 the tap is short. Currently, a storage tank or an instantaneous heat exchanger unit

90 (IHEU) are most commonly used for DHW production in single-family house. The

91 schematics of the DHW system configurations are shown in Fig. 2. 


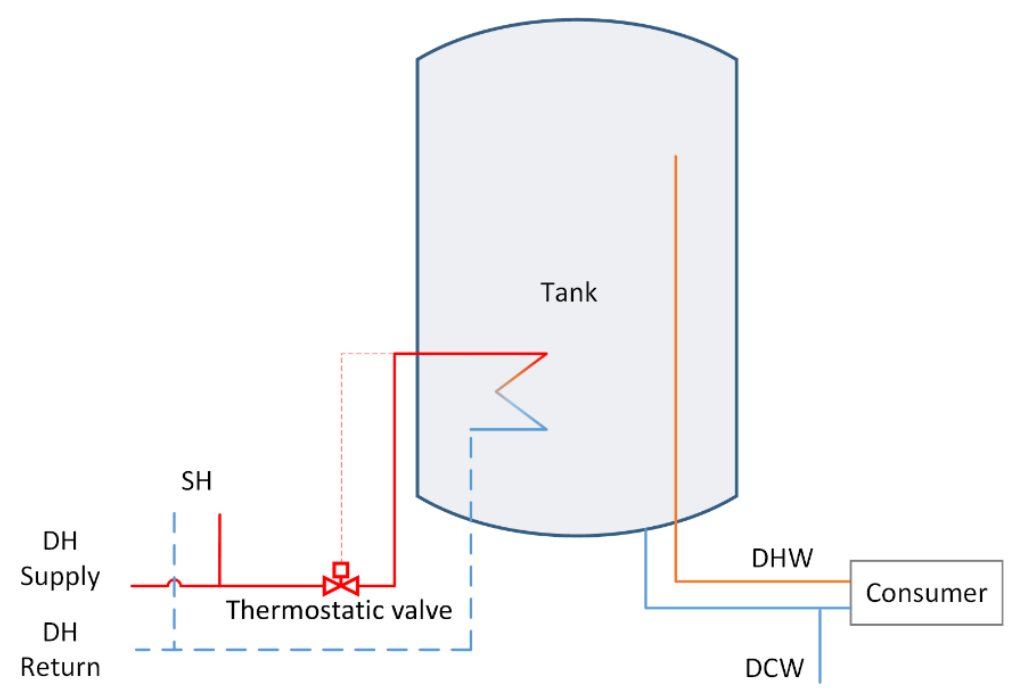

(a) DHW substation with a storage tank

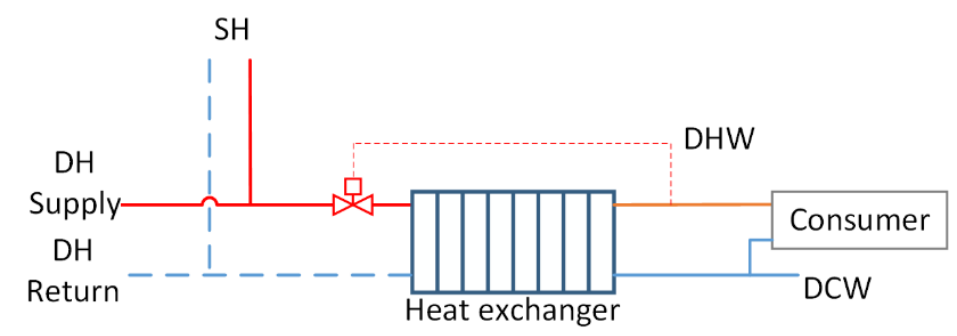

(b) DHW substation with an instantaneous heat exchanger (IHEU)

Fig. 2 Existing DHW configurations for single-family house

99 If the DHW is stored in a tank, the tank has to be maintained at no less than $60{ }^{\circ} \mathrm{C}$ to

100 avoid the risk of Legionella. Where an IHEU is used, bypass flow is required to ensure

101 the 10s waiting time for comfort reasons. These two existing methods can work properly with medium-temperature district heating without supplementary heating. 
103 1.2.2 Conventional DHW configurations in multi-storey building

104 For multi-storey building, depending on whether the DHW is prepared in the central

105 substation or locally, the configurations can be divided into mainly two types. The

106 schematics are shown in Fig. 3.

107

108

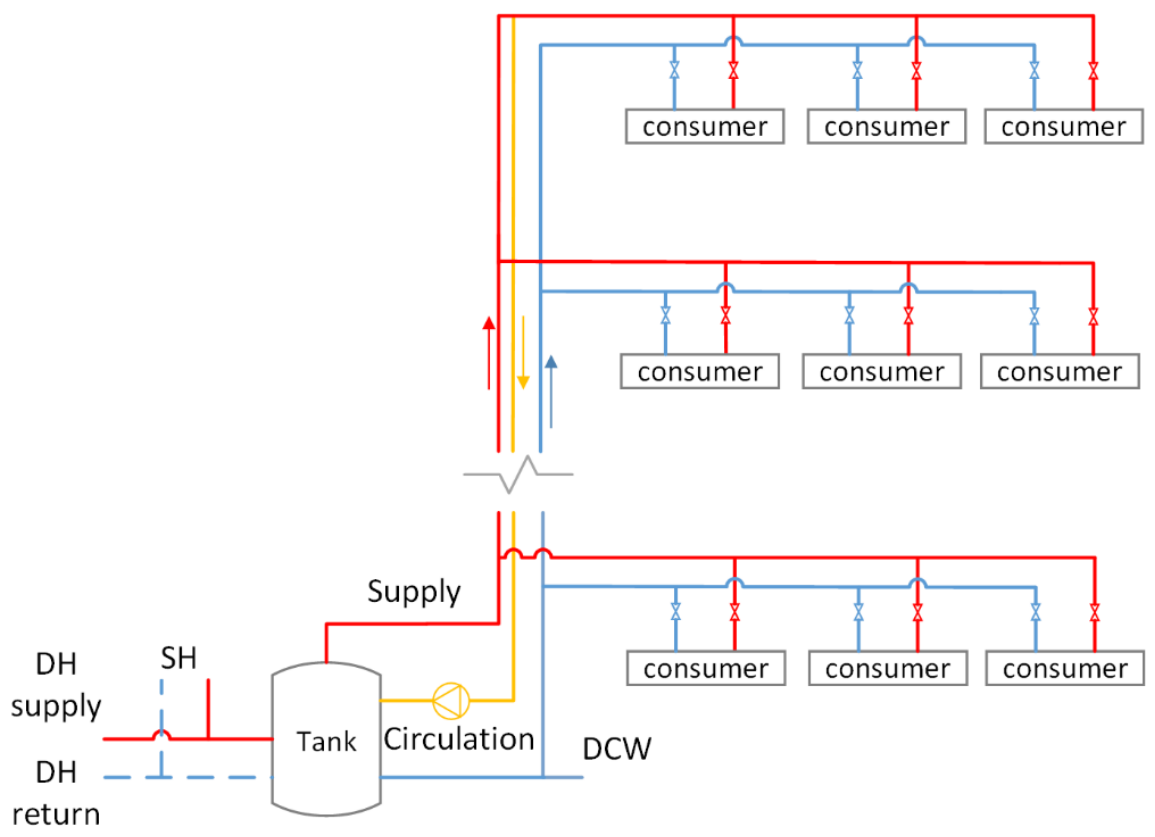

109

(a) Centralized system with a storage tanks and circulation circuit 


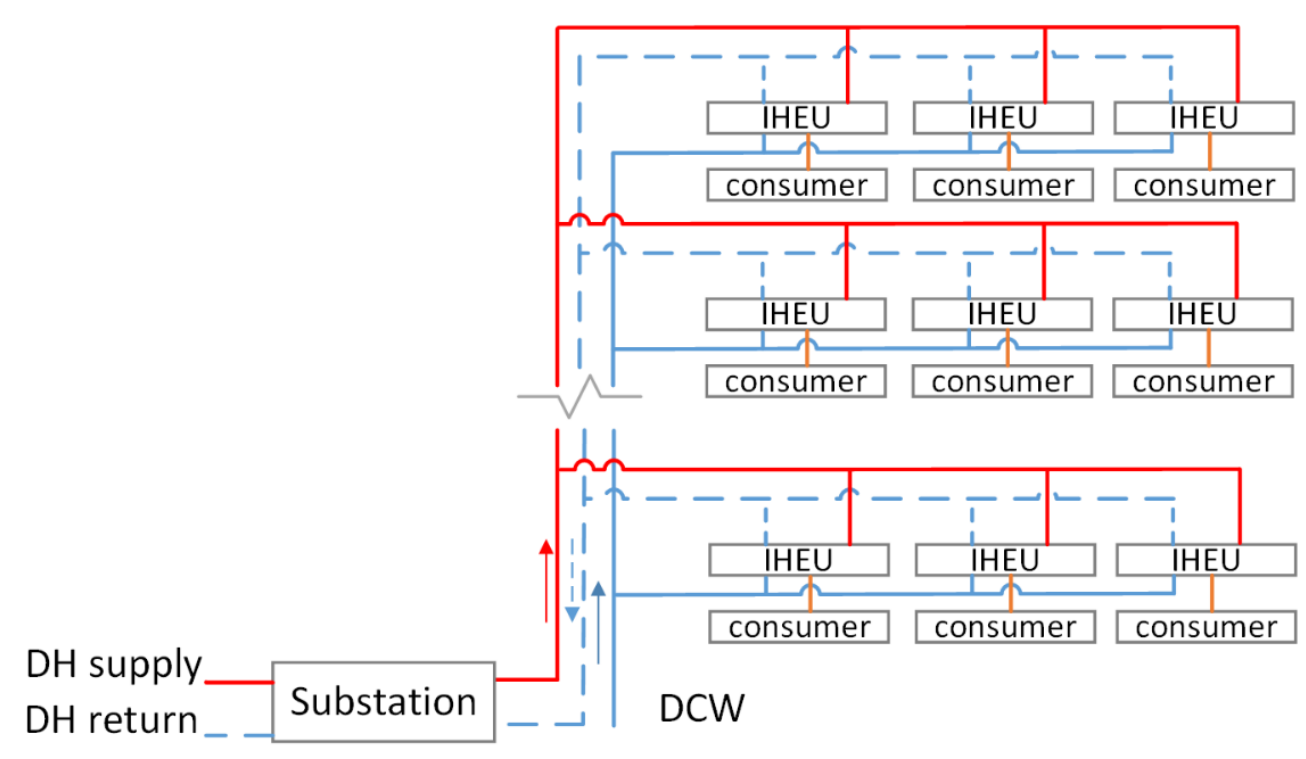

(b) Decentralized system with local heat exchanger (IHEU)

113 To take account of the overall DHW peak load and the comfort requirement, the DHW

114 shown in Fig. 3 (a) requires a storage tank to shave the peak load and circulation pipes

115 to ensure the 10 s waiting time. The cold and hot water are mixed at the faucet to reach

116 the desired temperature by the consumer. This study did not include systems only with

117 a main heat exchanger and circulation in the analysis for multi-storey buildings because

118 they are uncommon in Denmark. According to the standard for Legionella prevention

119 [4], a centralized system with DHW circulation requires the tank to be maintained at

$12060^{\circ} \mathrm{C}$ and the DHW circulation to be at least $50{ }^{\circ} \mathrm{C}$. Consequently, the heat loss from

121 such systems can be substantial. In Denmark, it has been found that the circulation

122 system can waste up to $70 \%$ of the total energy delivered for DHW use [3]. Moreover,

123 the high temperature regime for the circulation obstructs the implementation of

124 LTDH/UTLDH. In comparison, DHW can be prepared locally by the individual heat

125 exchanger as shown in Fig. 3. It is feasible to apply such a system with LTDH, but to 
126 ensure the 10s waiting time for comfort, bypass flow is always needed, which increases

127 the return temperature to district heating.

128 1.3 DHW preparing technologies

129 There are some investigations of different technologies for DHW preparation. . Cholewa

130 and et al. [5] test the performances of three different heating systems for multi-storey

131 buildings: a system with centralized condensing gas boiler, a system with flat-based heat

132 exchanger supplied by district heating, and a system with flat-based gas boiler. The

133 results show that both the decentralized systems have higher annual efficiency than the

134 centralised system. Thorsen [6] simulates the performance of flat-based heating unit

135 system combined with district heating based on a Danish case. The energy saving of the

136 flat-based heating unit system ranges from $2-4 \mathrm{kWh} / \mathrm{m}^{2}$ annually compared with the

137 conventional DHW circulation system and the system can be operated with lower supply

138 temperature without Legionella problem. Tol and Svendsen [7] simulate the district

139 heating network with different system layouts and substation configurations. They find

140 that the substation with a storage tank can help to reduce the heat loss at the end of

141 the branch network. Fernández-Seara and et al. [8] make experiment investigations for

142 the performances of DHW production system with a storage tank under 4 control

143 strategies. The result shows that the tank has better performance if the thermal

144 stratification can be maintained. Chaturvedi and et al. [9] model a solar-assisted heat

145 pump system for DHW production, and indicate that the life cycle cost of the solar-

146 assisted heat pump system is better than the electric only system if the water is heated

147 no higher than $70^{\circ} \mathrm{C}$. Brum and et al [10] model and compare three different heating 
148 systems for supplying space heating and domestic hot water to a 3-dwelling system. The

149 ground source heat pump consumes the least electricity for cover the equivalent DHW

150 demand, while the individual electric heater consumes the most. Bohm [11] makes

151 large-scale investigation towards the DHW preparation and distribution system in

152 Denmark, and indicates that the electric heat tracing cable can be used for maintaining

153 the DHW temperature at the tap, which is helpful to guarantee the comfort and hygiene

154 DHW supply from LTDH. However, the energy saving effect of the electric heat tracing

155 system can be offset by the high primary energy factor of the electricity. Yang and et al.

156 [12] make simulation of the electric heat tracing system for DHW supply to multi-storey

157 building by LTDH. The heat loss can be saved up by $70 \%$ compared with the

158 conventional heating system if the tracing cable is controlled corresponding to the DHW

159 load pattern. Ghoubali and et al. [13] make a simulation study of simultaneous heating

160 and cooling supply by heat pump, and find that the optimal seasonal coefficient of

161 performance of the heat pump is obtained if the DHW is produced at the temperature

$16240-45^{\circ} \mathrm{C}$. Elmegaard and et al. [14] investigate 3 heat pump systems as well as a direct

163 electric heating system for supplying heat with conventional district heating. The results

164 show that the heat pump system using R134a with a storage tank on the DH side has

165 better performance. Boait and et al [15] investigate five individual DHW systems, and

166 find the instantaneous DHW production is more efficient than storage type. In addition,

167 the insulation and smart control methods are of great importance to improve the

168 efficiency for DHW system with a storage tank or a heat pump. Lu and Wu[16] have

169 compared 8 different systems for covering the domestic energy demand. For DHW 
170 preparation, a system integrated an air conditioning unit and a heat pump has better

171 economy and environment performance, since the heat pump can extract indoor heat

172 for DHW production and provide cooling effect. However, most of the studies analyse

173 DHW preparation methods in isolation. The DHW preparation methods combined with

174 district heating are insufficiently studied. Moreover, the performances of the

175 approaches vary depending on the specific applying situations. Therefore, suitable

176 solutions for DHW preparation should be designed for LTDH and ULTDH, and broader

177 comparison among different solutions needs to be made, so that the optimal solutions

178 for specific scenarios can be determined.

179 1.4 Aim and scope

180 The aim of this study was to investigate optimal methods of supplying DHW from

181 LTDH/ULTDH while taking the comfort and hygiene requirements into account. To be 182 specific, it includes:

183 - Devise potential DHW configurations and operation methods to different scenarios

184 Evaluate the energy, economy and exergy performance of the devised solutions

185 - Suggest the optimal solutions of DHW supply within the LTDH or ULTDH scenario

186 In this study, various DHW supply methods were analysed in the context of different

187 generations of $\mathrm{DH}$ supply: medium-temperature district heating $\left(65^{\circ} \mathrm{C}\right), \mathrm{LTDH}\left(50^{\circ} \mathrm{C}\right)$

188 and ULTDH $\left(35^{\circ} \mathrm{C}\right)$. Different scenarios for the analysis were formed by combining

189 different DH systems with different building typologies. The performances of each

190 devised solution were calculated by the theoretical model ideally. Moreover, as an 
191 important factor for the system savings, the lowered return temperatures to district

192 heating in the different scenarios and the resulting cost savings were also investigated.

193 The results of this study can be helpful when planning for LTDH or even ULTDH in the

194 future.

\section{2. Material and Methods}

196 To fit the LTDH/ULTDH scenarios better, innovative DHW configuration were proposed

197 for different building typologies. Moreover, the operation methods corresponding to

198 each DHW supply system were carefully designed to meet the comfort and hygiene

199 requirements. The potential solutions that comprise the DHW configuration and

200 operation are illustrated in this section, sorted by the different DH systems to applied

201 with. Calculation models were built to evaluate the energy, economy, and exergy

202 performances of the proposed DHW systems. The bases are the energy and exergy

203 balance equations. The theories are explained in Section 2.3 .

2042.1 Solutions for DHW supply with low-temperature district heating (LTDH)

205 Three types of solutions were proposed for LTDH:

206 1) A central heat exchanger combined with a heat pump, which could be a solution for

207 DHW supply with LTDH in multi-storey buildings where substantial renovations are

208 not feasible.

209 2) An IHEU system with better-insulated distribution pipes and using bypass flow for

210 bathroom floor heating, which can be applied with LTDH for both single-family 
211 houses and multi-storey buildings. This would be best in new buildings or in existing

212 buildings where deep renovation for the space heating and DHW system is possible.

213 3) Electric heat tracing combined with dynamic control. This could be applied in multi-

214 storey buildings where the DHW circulation pipes can be replaced and in buildings

215 that have special requirements for DHW hygiene, such as hospitals or nursing

216 homes.

217 2.1.1 Central heat exchanger combined with heat pump

218 The central heat exchanger is used to replace the heat storage tank, which generates

219 huge heat losses. In a typical multi-storey building with 6 floors and 3 apartments on

220 each floor, the simultaneity factor is only 0.1. Therefore, the impact of the increased

221 peak load to the network due to the removal of the storage tank is insignificant for large

222 buildings. A schematic of this solution is shown in the following diagram: 
224

233 efficiently reduced without being influenced by the DHW circulation.

$234 \quad 2.1 .2$ Improved decentralized system with instantaneous heat exchanger unit (IHEU)

235 The schematics are similar to those shown in Fig. 2 (b) and Fig. 3 (b), but the heat

236 exchanger needs optimized design to improve the efficiency with low supply

237 temperature, so that comfort temperature of $\mathrm{DHW}\left(45^{\circ} \mathrm{C}\right)$ and low return temperature 
238 can be achieved. The DHW is prepared instantaneously through the IHEU, so the

239 capacity of the unit needs to be sufficient to cover the peak load for DHW, which is 32.3

$240 \mathrm{~kW}$ [17]. The conventional way of operating IHEUs requires a bypass to ensure the 10s

241 waiting time. However, mixing the bypass flow with the $\mathrm{DH}$ return flow will increase the

242 return temperature to district heating, which limits the efficiency of LTDH. One possible

243 improvement might be to redirect the bypass flow to bathroom heating, so that the

244 return temperature can be much reduced after heating the bathroom. According to the

245 Danish building code, the air change rate in the bathroom is 15L/s [18]. To keep the tiled

246 bathroom floor at a comfort temperature of $24-29^{\circ} \mathrm{C}, 116 \mathrm{~W}$ space heating demand is

247 required for each home for only heating the air flow through the bathroom from $20^{\circ} \mathrm{C}$

248 to $26^{\circ} \mathrm{C}$. If the insulation of the supply pipe is adequate, the bathroom heating flow will

249 be able to reach the end user with very limited temperature drop, and keep the supply

250 pipe warm. As a result, the space heating demand may increase during the non-heating

251 season, but cost savings will be available in the DH system due to the reduced return

252 temperature to district heating. Moreover, the thermal comfort of the bathroom will be

253 improved.

\section{$254 \quad 2.1 .3$ Electric heat tracing}

255 Electric heat tracing uses electric tracing cable as supplementary heating for LTDH. The

256 cable power is adjustable along with the difference between the set-point temperature

257 and the temperature of the supply pipe, so that more precise temperature control can

258 be achieved. The schematic of an electric heat tracing system is shown in the following

259 diagram: 


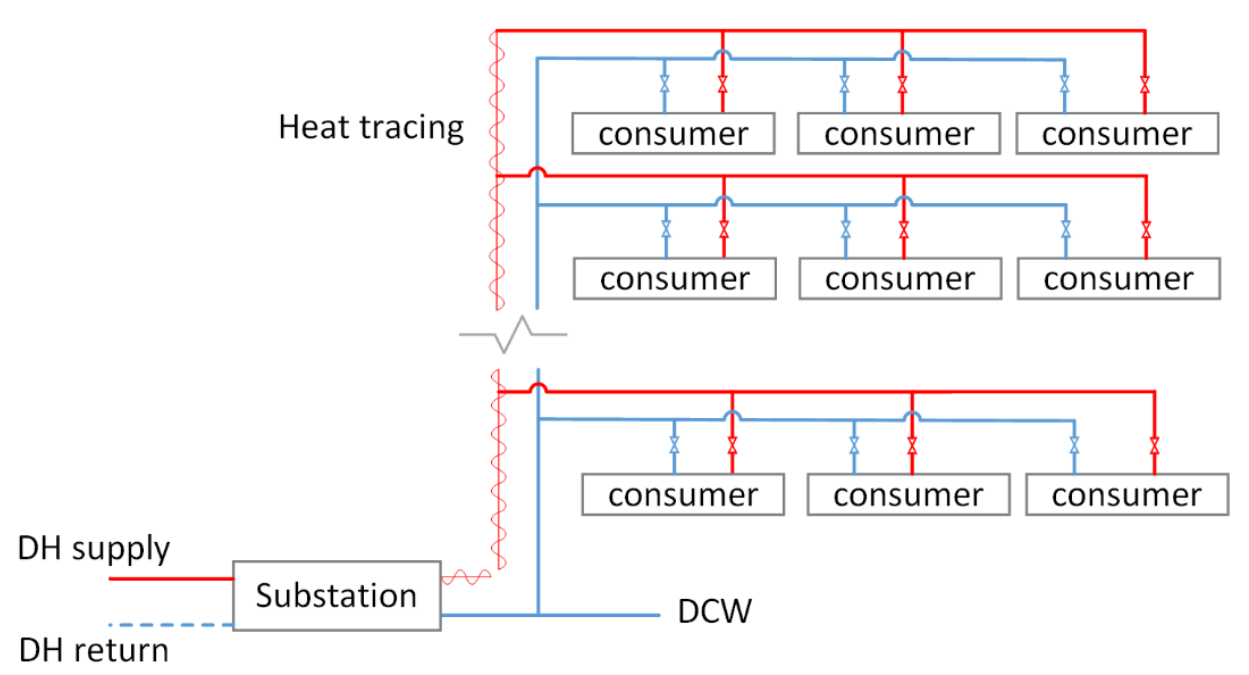

262 Since the supply line can be kept warm by the electric tracing cable, the storage tank

263 and circulation pipe are unnecessary, saving much heat loss. Compared to the

264 conventional system with DHW circulation, the electric heat tracing system can reduce

265 the distribution heat loss by $50 \%$ [12]. The electricity consumption of the electric heat

266 tracing system depends greatly on the control method. Smart control methods of the

267 cable based on DH load profile plays a role in saving the power consumption.

268 2.2 Solutions for DHW supply with ultra-low-temperature district heating (ULTDH)

269 Since ULTDH is insufficient to heat DHW to the temperature required by the comfort or

270 hygiene regulations, supplementary heating is needed. One solution is the IHEU

271 combined with an electric micro tank, which can be easily installed in a new building or

272 an existing building with IHEU. Another solution is the micro heat pump system, which is

273 applicable for single-family houses. 
274 2.2.1 Combination of IHEU and micro tank

275 The instantaneous electric heater can heat DHW to the required temperature

276 instantaneously, but when the DH supply temperature is much lower than the comfort

277 temperature $\left(45^{\circ} \mathrm{C}\right)$, the electricity peak load can be very high, which makes it difficult

278 to install with the normal power supply. To address this problem, this study proposes

279 the new concept of using a micro tank with immersion heater to shave the peak power

280 load. A schematic of the micro tank solution is shown in the following diagram:

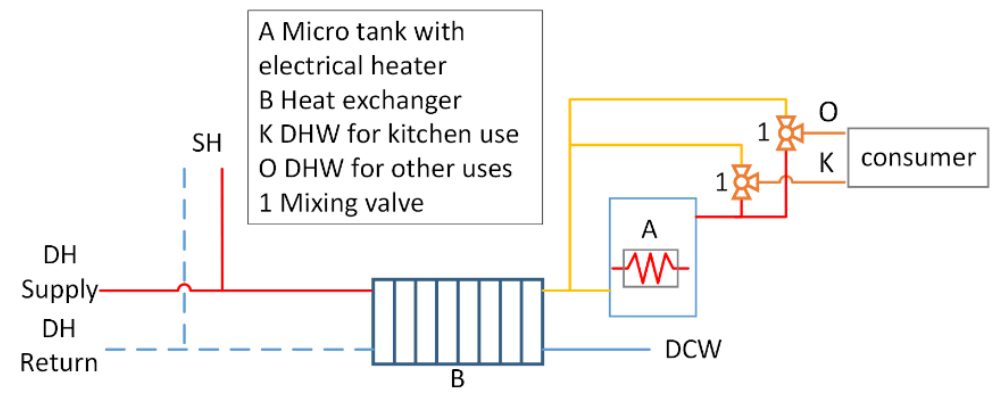

(a) Implementation for single-family house

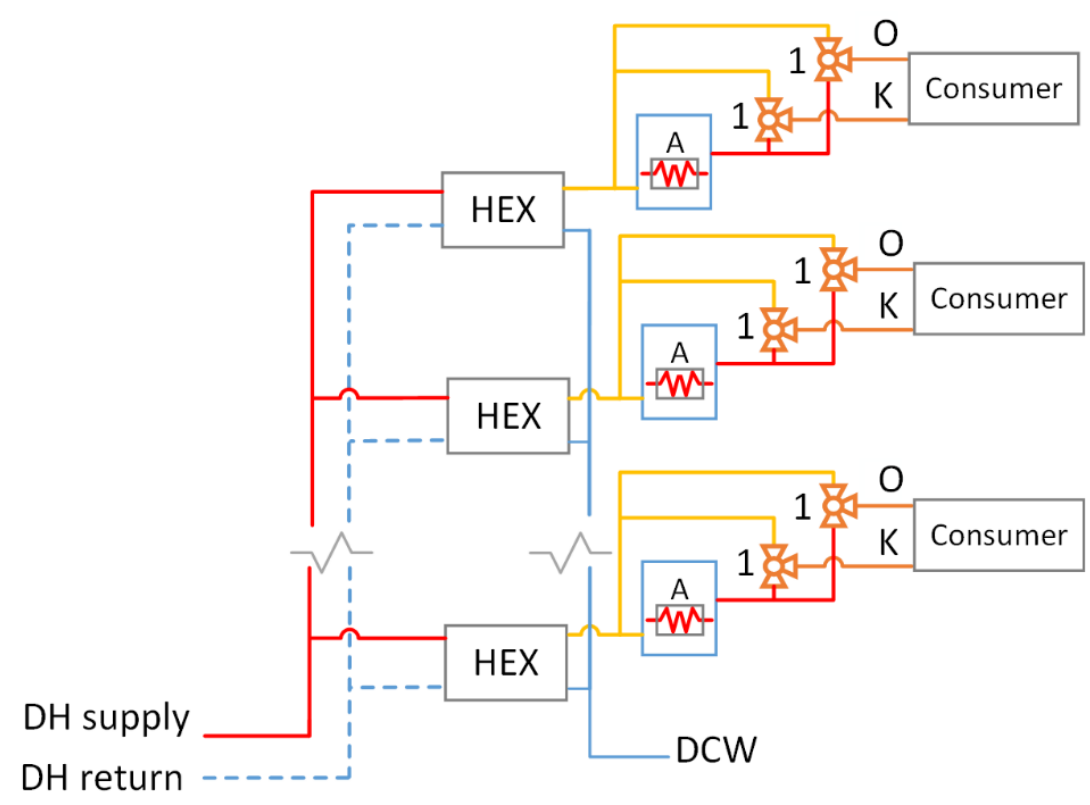

(b) Implementation for multi-storey building 
286 The micro tank with an immersion electric heater is installed on the consumer side. The

287 DHW is preheated by ULTDH through the heat exchanger. One stream of the preheated

288 DHW is stored and further heated in the micro storage tank. To meet the requirement

289 of Legionella prevention, the $\mathrm{DHW}$ in the tank is heated to $60^{\circ} \mathrm{C}$ by the electric

290 immersion heater. When DHW is drawn off, the DHW from the tank is mixed with the

291 hot water preheated by the heat exchanger to achieve the comfort temperature. There

292 are two thermostatic valves controlling the mixed temperature of DHW for kitchen use

$293\left(45^{\circ} \mathrm{C}\right)$ and for other uses $\left(40^{\circ} \mathrm{C}\right)$. Compared to the instantaneous electric heater, the

294 micro tank solution can be designed to be compatible with the normal electricity supply.

295 Moreover, since the micro tank can provide DHW immediately, no bypass is needed for

296 the heat exchanger in this solution, so the average $\mathrm{DH}$ return temperature is also

297 reduced. The micro tank system can be applied in both single-family houses and multi-

298 storey buildings with instantaneous heat exchanger units.

299 2.2.2 Micro heat pump

300 A micro heat pump can be used as local booster for ULTDH with high thermodynamic

301 efficiency. It can be applied in single-family houses. The schematic of a micro heat pump

302 system is shown in Fig. 7. 


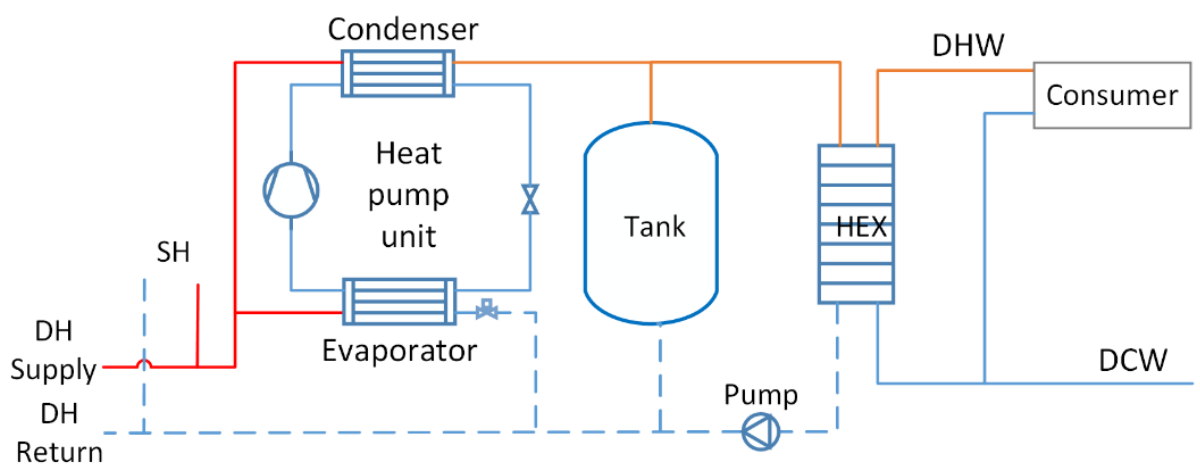

305 The heat source of the heat pump is ULTDH supply water. The electricity is only used to

306 lift the energy quality of the $\mathrm{DH}$ water. Compared to direct electric heating, therefore,

307 the micro heat pump system consumes much less electricity than other supplementary

308 heating devices to heat an equivalent amount of DHW. The storage tank helps to

309 maintain stable operating conditions for the heat pump. Since the tank is installed on

310 the primary side, the risk of Legionella is eliminated

\section{$311 \quad 2.3$ Evaluation models for different scenarios}

312 Three DH scenarios were defined as the background for the evaluation models: 1)

313 medium-temperature district heating (MTDH) with a supply temperature of $65^{\circ} \mathrm{C}$, which

314 ensures the comfort and hygiene of DHW supply without any supplementary heating.

315 This scenario can be considered as the first step of the transition to $4^{\text {th }}$ generation

316 district heating. The conventional DHW system can be retained in this phase. 2) Low-

317 temperature district heating (LTDH) with a supply temperature of $50{ }^{\circ} \mathrm{C}$, which is

318 sufficient to heat DHW to a comfortable temperature, but which will require certain

319 solutions to prevent Legionella. 3) Ultra-low-temperature district heating (ULTDH) with 
320 a supply temperature of $35^{\circ} \mathrm{C}$, which is insufficient to meet either comfort or hygiene

321 requirements.

322 Two building typologies were considered to build different scenarios: the single-family

323 house and the multi-storey building. To formulate the reference DHW demand for the

324 models, the single-family house in this study was assumed to have an overall floor area

325 of $150 \mathrm{~m}^{2}$, while the apartment in a multi-storey building was assumed to have an area

326 of $90 \mathrm{~m}^{2}$. The indoor DHW distribution systems of each building topology are assumed

327 to be identical, therefore, they are excluded from the comparison for different

328 scenarios. The multi-storey building was assumed to have six floors with three

329 apartments on each floor, which is typical in Denmark. To make the analyses more

330 comparable, the evaluation models were based on individual homes. This means that,

331 for the multi-storey building, the evaluation results were specified for one apartment.

332 In accordance to the specific application conditions and operation methods, the

333 performances of the DHW preparation method in each scenario are investigated by

334 theoretical calculation models. The assumptions and basic equations for the energy,

335 economy and exergy models are described separately.

\section{$336 \quad$ 2.3.1 Evaluation model for energy performance}

337 The energy performance model evaluates the DH heat and electricity consumption for

338 DHW preparation, also including heat loss from the equipment and distribution pipes

339 inside the building. The relative $\mathrm{DH}$ heat and electricity consumption depend on the 
340 different DHW system configurations and corresponding operating temperatures. The

341 operating temperature for each case was as described in previous sections.

342 The total energy consumption for DHW preparation, as one indicator of the energy

343 performance of the DHW system investigated, can be calculated as:

344

$$
Q_{t o t}=Q_{d h w}+Q_{e q}+Q_{p}
$$

345 where

$346 Q_{t o t}$ is the total energy consumption [kWh],

$347 Q_{d h w}$ is the DHW heat demand [kWh],

$348 Q_{e q}$ is the heat loss from the equipment $[\mathrm{kWh}]$,

$349 Q_{p}$ is the heat loss from the distribution pipe inside the building [kWh].

350 To make the cases of each building topologies comparable, all the DHW preparing

351 methods were modelled to meet the same DHW demand, with a standardized volume

$352\left(250 \mathrm{~L} / \mathrm{m}^{2} \cdot \mathrm{yr}\right)$ of $\mathrm{DHW}[19,20]$ produced at a comfortable temperature $\left(45^{\circ} \mathrm{C}\right)$, assuming

353 that the required energy for DHW preparation can be much reduced due to the

354 evolution of new technologies and efficient operation in the future. Considering the

355 different operation modes, some systems may prepare DHW at a higher temperature

356 due to the threat of Legionella, but the tap temperature can be adjusted to $45^{\circ} \mathrm{C}$

357 ultimately by mixing with DCW. 
358 The information of the storage tank was derived from standard products solutions. For

359 the single-family house, the storage tank was $160 \mathrm{~L}$ with a heat loss rate of $60 \mathrm{~W}$, while

360 for the multi-storey building the tank was $1000 \mathrm{~L}$ with a heat loss rate of $113 \mathrm{~W}$. For the

361 micro-tank system, the tank was assumed to be $60 \mathrm{~L}$ with a $2 \mathrm{~kW}$ immersion electric

362 heater, so that combined with ULTDH, it would be able to cover the peak demand of

363 one kitchen tapping and one shower happening at the same time (1.1 kWh) within a 20-

364 minute interval [17]. The heat loss rate of the micro tank was calculated from the

365 insulation standard [21] as $14 \mathrm{~W}$. The heat loss rate of the micro heat pump system was

366 based on information from the manufacturer, and it consists of a heat loss rate of $60 \mathrm{~W}$

367 for the tank and 40W for the compressor. With regard to the system with a central heat

368 exchanger and heat pump, there was no auxiliary tank, so the equipment heat loss was

369 assumed to be $40 \mathrm{~W}$ for the compressor of the heat pump. The heat exchanger was

370 assumed to be well insulated, so that the heat loss would be negligible compared to the

371 energy needed for heating the DHW. For the multi-storey building, the equipment heat

372 loss was assumed to be allotted to all the flats equally.

373 Heat loss from the distribution pipes inside the buildings was only taken into account for

374 the multi-storey building. The distribution heat loss inside each apartment was not

375 included in the model since it can be identical for all cases. For the systems with bypass

376 or circulation, each flat was assumed to have $6 \mathrm{~m}$ of distribution pipe. For the electric

377 heat tracing system, the distribution pipe only included $3 \mathrm{~m}$ supply pipe in the model.

378 The pipe diameter of the riser was assumed to $40 \mathrm{~mm}$, while the diameter of the

379 circulation pipe was assumed to $15 \mathrm{~mm}$. Advanced pipe insulation with polyurethane 
380 foam was selected for the model, the corresponding heat coefficients are $0.157 \mathrm{~W} / \mathrm{m}^{*} \mathrm{~K}$

381 and $0.094 \mathrm{~W} / \mathrm{m}^{\prime} \mathrm{K}$ according to the existing product. The ambient temperature for

382 calculating the heat loss was assumed to be $15^{\circ} \mathrm{C}$.

383 Typically, the DHW draw-off period only accounts for $1 \%$ of the day [22]. Therefore, the

384 circulation or bypass was assumed to be operated continuously for the corresponding

385 system, and the pipe temperature was approximated to circulation temperature or

386 bypass temperature. For the micro tank solution that has no bypass operation, during

387 the non-tapping period, the distribution pipe was assumed to be cooled down to the

388 ambient temperature, and the pipe heat loss was negligible.

389 The heat loss from the pipe can be calculated as

390

$$
Q_{p}=\sum L_{i} * q_{i} *\left(t_{i}-t_{a m b}\right) * \tau
$$

391 where

$392 L_{i}$ is the length of the supply/return/circulation pipe counted for one apartment [m],

$393 q_{i}$ is the heat loss rate from the corresponding pipe $[\mathrm{kW} / \mathrm{m} \cdot \mathrm{K}]$,

$394 t_{i}$ is the average temperature of the counted pipe $\left[{ }^{\circ} \mathrm{C}\right]$,

$395 t_{a m b}$ is the ambient temperature $\left[{ }^{\circ} \mathrm{C}\right]$,

$396 \tau$ is the time of the calculation period [h].

397 As an important performance parameter, the volume-based average return

398 temperatures to district heating of the different scenarios were investigated. For the 
storage tank system with $\mathrm{MTDH}$, the average return temperature to district heating was

400 calculated based on the design return temperature in the product catalogue and the

401 energy balance of the practical situation. For the IHEU system, the return temperature

402 to district heating was calculated as the volume-averaged return temperature of the

403 water-heating flow and the bypass flow for the MTDH scenario. The supply/return

404 service pipe was assumed to be $5 \mathrm{~m}$ long, which connects the building to the DH

405 transmission network. The set-point temperature of the bypass was assumed to be

$40645^{\circ} \mathrm{C}$ to ensure the 10 s waiting time required by the comfort standard $[17,20]$. The

407 flowrate of the bypass should be sufficient to provide $45^{\circ} \mathrm{C}$ to the most remote

408 consumer. For the LTDH scenario, the bypass of the IHEU was redirected to bathroom

409 heating to reduce the return temperature to district heating. Thus, the volume-based

410 average return temperature was calculated from the water-heating flow and the

411 bathroom-heating flow. The return temperature of the bathroom-heating flow was

412 assumed to be $25^{\circ} \mathrm{C}$ with effective cooling. With effective heat exchanger, the water-

413 heating flow at the outlet of the IHEU can be cooled down to $20^{\circ} \mathrm{C}$ for MTDH and

$41418.8^{\circ} \mathrm{C}$ for $\operatorname{LTDH}[19,23]$. The bypass flow and the bathroom-heating flow can be

415 calculated as follows:

$$
V_{\text {bypass }}=L_{\text {bypass }} * q_{i} *\left(t_{i}-t_{\text {amb }}\right) /\left(\Delta t_{\text {bypass }} * 4200\right) * 3600 * 24
$$

$$
V_{b a t h}=q_{b a t h} /\left(\left(t_{b s}-t_{b r}\right) * 4200\right) * 3600 * 24
$$

418 Where

$419 V_{\text {bypass }}$ is the bypass flowrate on daily basis [L/day], 
$420 L_{\text {bypass }}$ is the pipe length including the service pipe and distribution pipe [m],

$421 \Delta t_{\text {bypass }}$ is the temperature drop of the bypass flow along the supply line $\left[{ }^{\circ} \mathrm{C}\right]$,

$422 V_{\text {bath }}$ is the bathroom heating flowrate on daily basis [L/day],

$423 q_{\text {bath }}$ is the space heating demand of the bathroom (116W/apartment according to

424 section 3.2$)[W]$,

$425 t_{b s}$ is the supply temperature to bathroom heating $\left[{ }^{\circ} \mathrm{C}\right]$,

$426 t_{b r}$ is the return temperature from bathroom heating [ $\left.{ }^{\circ} \mathrm{C}\right]$.

427 Therefore, the return temperature to district heating of the IHEU system can be

428 calculated as:

429

$$
\overline{t_{r e t}}=\left(t_{d e} * V_{w h}+t_{b} * V_{b}\right) /\left(V_{w h}+V_{b}\right)
$$

430 where

$431 \overline{t_{r e t}}$ is the volume-averaged return temperature $\left[{ }^{\circ} \mathrm{C}\right]$,

$432 t_{d e}$ is the design return temperature of the IHEU [ $\left.{ }^{\circ} \mathrm{C}\right]$,

$433 t_{b}$ is the temperature of the bypass flow (MTDH) or bathroom heating return flow

434 (LTDH) $\left[{ }^{\circ} \mathrm{C}\right]$,

$435 V_{w h}$ is the volume of the IHEU water heating flow on a daily basis [L/day],

$436 V_{b}$ is the volume of the bypass (MTDH) or bathroom heating flow (LTDH) on a daily basis

$437 \quad[$ L/day $]$. 
438 For the solutions with a heat pump, the design COP is 4.5 according to the existing

439 product. The return temperature to district heating was calculated as the volume-

440 averaged temperature of the return flow from the evaporator of the heat pump and the

441 flow for DHW preparation. The ratio between the two volumes can be obtained from

442 the energy balance of the heat pump, assuming the water-heating flow equals the $\mathrm{DH}$

443 flow to the heat pump condenser. For the micro tank solution and the electric heat

444 tracing solution, the design return temperature from the heat exchanger catalogue was

445 used.

446 The parameters for the energy evaluation model are shown in the Table 2 and Table 3

447 for the single-family house and the multi-storey building, respectively:

448 Table 2 Input parameters for the energy evaluation model for the single-family house

\begin{tabular}{|c|c|c|c|c|c|}
\hline & \multicolumn{5}{|c|}{ Single family house } \\
\hline & MTDH & & $\mathrm{LTDH}$ & ULTDH & \\
\hline & With tank & IHEU & IHEU & Micro tank & $\begin{array}{l}\text { Micro heat } \\
\text { pump }\end{array}$ \\
\hline Energy sources & $\mathrm{DH}$ & $\mathrm{DH}$ & $\mathrm{DH}$ & $\mathrm{DH} \& \mathrm{EL}$ & $\mathrm{DH} \& \mathrm{EL}$ \\
\hline T_dh_supply $\left[{ }^{\circ} \mathrm{C}\right]$ & 65 & 65 & 50 & 35 & 35 \\
\hline $\mathrm{T}_{-} \mathrm{dcw}\left[{ }^{\circ} \mathrm{C}\right]$ & 10 & 10 & 10 & 10 & 10 \\
\hline$V_{-} d h w\left[L / m^{2} /\right.$ year $]$ & 250 & 250 & 250 & 250 & 250 \\
\hline T_dhw $\left[{ }^{\circ} \mathrm{C}\right]$ & 45 & 45 & 45 & 30 & 30 \\
\hline $\begin{array}{l}\text { Set point } \mathrm{T} \text { of the } \\
\text { equipment }\left[{ }^{\circ} \mathrm{C}\right]\end{array}$ & 60 & - & - & 60 & 50 \\
\hline $\begin{array}{l}\text { Equipment heat loss } \\
\text { rate }[\mathrm{W}]\end{array}$ & $\begin{array}{l}60 \mathrm{~W} \text { for } \\
\text { tank }\end{array}$ & - & - & $\begin{array}{l}14 \mathrm{~W} \text { for } \\
\text { micro tank }\end{array}$ & $\begin{array}{l}100 \mathrm{~W} \text { for } \\
\text { heat pump }\end{array}$ \\
\hline
\end{tabular}


450 Table 3 Input parameters for the energy evaluation model for the multi-storey building

\begin{tabular}{|c|c|c|c|c|c|c|}
\hline & & & Multi-storey & uilding & & \\
\hline & $\mathrm{MTDH}$ & & LTDH & & & \\
\hline & $\begin{array}{l}\text { With tank and } \\
\text { circulation }\end{array}$ & IHEU & $\begin{array}{l}\text { Central HEX } \\
\text { and HP }\end{array}$ & IHEU & El-tracing & Micro tank \\
\hline Energy sources & $\mathrm{DH}$ & $\mathrm{DH}$ & $\mathrm{DH} \& \mathrm{EL}$ & $\mathrm{DH}$ & $\mathrm{DH} \& \mathrm{EL}$ & $\mathrm{DH} \& \mathrm{EL}$ \\
\hline DH supply Temp. $\left[{ }^{\circ} \mathrm{C}\right]$ & 65 & 65 & 50 & 50 & 50 & 35 \\
\hline DCW Temp. $\left[{ }^{\circ} \mathrm{C}\right]$ & 10 & 10 & 10 & 10 & 10 & 10 \\
\hline $\begin{array}{l}\text { Standardized volume of } \\
\text { DHW }\left[\mathrm{L} / \mathrm{m}^{2} / \text { year }\right]\end{array}$ & 250 & 250 & 250 & 250 & 250 & 250 \\
\hline $\begin{array}{l}\text { DHW Temp. heated by } \\
\mathrm{DH}\left[{ }^{\circ} \mathrm{C}\right]\end{array}$ & 45 & 45 & 45 & 45 & 45 & 30 \\
\hline $\begin{array}{l}\text { Set point } \mathrm{T} \text { of the } \\
\text { equipment }\left[{ }^{\circ} \mathrm{C}\right]\end{array}$ & 60 & - & 50 & - & 50 & 60 \\
\hline $\begin{array}{l}\text { Equipment heat loss } \\
\text { rate }[\mathrm{W}]\end{array}$ & $113 \mathrm{~W}$ for tank & - & $\begin{array}{l}\text { 40W for } \\
\text { compressor }\end{array}$ & - & - & $\begin{array}{l}14 \mathrm{~W} \text { for } \\
\text { micro tank }\end{array}$ \\
\hline Pipe heat loss & Pipe_r: 0.157 & 0.157 & Pipe_r: 0.157 & 0.157 & 0.157 & 0.157 \\
\hline coefficient $[\mathrm{W} / \mathrm{m} \cdot \mathrm{K}]$ & Pipe_c: 0.094 & & Pipe_c: 0.094 & & & \\
\hline $\begin{array}{l}\text { Distribution pipe length } \\
\text { per flat }[\mathrm{m}]\end{array}$ & 6 & 6 & 6 & 6 & 3 & 6 \\
\hline
\end{tabular}

451 *Pipe_r means the riser, Pipe_c means the circulation pipe.

452 2.3.2 Evaluation model for economic performance

453 Economic performance depends on the investment cost, operation and maintenance

$454(\mathrm{O} \& M)$ costs, and the energy cost. However, the investment cost and O\&M costs are

455 strongly dependent on the specific case, so only the DH heat and electricity costs were

456 included in the economic model. The prices of $\mathrm{DH}$ heat and electricity were assumed to

457 be $0.1[24]$ and $0.25[25] € / k W h$, respectively.

$$
C_{t o t}=Q_{d h} * P_{d h}+Q_{e l} * P_{e l}
$$


459 where

$460 C_{t o t}$ is the total energy cost $[€]$,

$461 Q_{d h}, Q_{e l}$ are the consumptions for heat and electricity [kWh],

$462 P_{d h}, P_{e l}$ are the prices of district heating and electricity respectively [ $\left.€ / \mathrm{kWh}\right]$.

463 In addition to the savings inside buildings, the benefits of low return temperatures to

464 the DH system was also investigated for each scenario. According to Svend and Sven

465 [22], the cost reduction from the low return temperature is estimated to be 0.16

466 EURO/MWh ${ }^{\circ} \mathrm{C}$. The cost reduction due to the low return temperature comparing to

467 the conventional $80 / 40{ }^{\circ} \mathrm{C} \mathrm{DH}$ scenario was therefore calculated.

468

$$
E_{s}=\varepsilon \cdot Q_{\text {sup }} \cdot \Delta t
$$

469 Where,

$470 E_{s}$ is the cost reduction for the DH system [EURO/year],

$471 \varepsilon$ is the cost saving ratio, here is $0.16\left[\mathrm{EURO} / \mathrm{MWh} \cdot{ }^{\circ} \mathrm{C}\right]$,

$472 Q_{\text {sup }}$ is the total heat consumption for DHW supply [MWh/year],

$473 \Delta t$ is the temperature difference between the calculated return temperature of the

474 suggested solution and the conventional return temperature to $\mathrm{DH}$, here the

475 conventional return temperature is $40\left[{ }^{\circ} \mathrm{C}\right]$. 


\section{$476 \quad$ 2.3.3 Evaluation model for exergy performance}

477 To indicate the energy quality and the utilization efficiency of each DHW supply method,

478 the exergy and exergy efficiency were calculated. The object systems for the exergy

479 analysis in this study was confined to the DHW supply system in the building sector. The

480 changes in kinetic and potential exergy were neglected [26], only physical exergy of the

481 flow was considered. The reference pressure and temperature were assumed to be

482 constant. The reference temperature was assumed to be $7.7^{\circ} \mathrm{C}$, which is the annual

483 average ambient temperature in Denmark. The exergy efficiency of the DHW supply

484 system was considered as the ratio of the exergy flow leaving the system to the exergy

485 flow entering the system. The analysis methods described in reference [26] were used in

486 this study. The exergy efficiency can be calculated as:

$$
E x_{\text {out }}=Q_{d h w}\left(1-\frac{T_{0}}{T_{d h w}-T_{d c w}} \ln \frac{T_{d h w}}{T_{d c w}}\right)
$$

$$
E x_{i n}=Q_{d h}\left(1-\frac{T_{0}}{T_{s u p}-T_{r e t}} \ln \frac{T_{\text {sup }}}{T_{\text {ret }}}\right)+W_{e l}
$$

490 where

$491 \eta_{e x}$ is the exergy efficiency of the DHW supply system [\%],

$492 E x_{\text {in }}, E x_{\text {out }}$ are the exergy flow entering and leaving the object system [kWh],

$493 Q_{d h w}$ is the DHW heat demand [kWh],

$494 T_{0}$ is the temperature of the reference state $\left[{ }^{\circ} \mathrm{C}\right]$, 
$495 T_{d h w}, T_{d c w}$ are the temperatures of DHW and DCW, which were assumed to be 45 and

49610 respectively $\left[{ }^{\circ} \mathrm{C}\right]$,

$497 \boldsymbol{T}_{\text {sup }}, \boldsymbol{T}_{\boldsymbol{d c w}}$ are the supply and return temperatures of the district heating water $\left[{ }^{\circ} \mathrm{C}\right]$,

$498 Q_{d h}$ is the supply heat from district heating [kWh],

$499 W_{e l}$ is the electricity consumption for DHW supply, which can be completely converted

500 into useful work [kWh].

501 3. Results

$502 \quad 3.1$ Results of the energy performance evaluation

503 The results of the DHW- heating flow, the bypass flow and the bathroom-heating flow of

504 the IHEU system are shown in Table 4.

505 Table 4 Daily water-heating flow, bypass flow and bathroom heating flow in the IHEU system

\begin{tabular}{|c|c|c|c|c|}
\hline & \multicolumn{2}{|c|}{ Single-family house } & \multicolumn{2}{|c|}{ Multi-storey building } \\
\hline & IHEU with & IHEU with & IHEU with & IHEU with \\
\hline & MTDH & LTDH & MTDH & LTDH \\
\hline Water-heating flow [L/day] & 79.9 & 115.3 & 863 & 1244.7 \\
\hline Bypass flow [L/day] & 32.3 & (104.9) & 148.6 & $(482.8)$ \\
\hline Bathroom heating flow [L/day] & - & 119.3 & - & 2147.6 \\
\hline
\end{tabular}

506 * The flow for the multi-storey building in the table is the overall value for the hypothetical 507 building

508 From the results, a single-family house supplied by MTDH required 19.4 L/day bypass

509 flow to keep the set-point temperature of the bypass at $45^{\circ} \mathrm{C}$, while $140 \mathrm{~L} /$ day bypass

510 flow was required for a 6-floor multi-storey building. The bypass flows of the LTDH

511 scenario were calculated only for comparing with the bathroom heating flow, so that to

512 verify the feasibility of using bathroom heating to keep the supply pipe warm. 
513 Comparing the results in Table 4, the bathroom heating flows are larger than the

514 required bypass flow, which indicates smaller temperature drop along the supply pipe.

515 Therefore, the bypass function can be replaced by the bathroom heating flow. The flows

516 in Table 4 were used to calculate the volume-averaged return temperature of the IHEU

517 systems.

518 The average return temperatures to district heating of each system are shown in Table 5

519 and Table 6.

520 Table 5 Average return temperatures to district heating for single-family house systems

\begin{tabular}{|c|c|c|c|c|c|}
\hline & \multicolumn{5}{|c|}{ Single family house } \\
\hline & MTDH & & LTDH & ULTDH & \\
\hline & With tank & $\begin{array}{l}\text { IHEU with } \\
\text { bypass }\end{array}$ & $\begin{array}{l}\text { IHEU with } \\
\text { bathroom heating }\end{array}$ & $\begin{array}{l}\text { Micro } \\
\text { tank }\end{array}$ & $\begin{array}{l}\text { Micro heat } \\
\text { pump }\end{array}$ \\
\hline \multicolumn{6}{|l|}{ Average return } \\
\hline temperature $\left[{ }^{\circ} \mathrm{C}\right]$ & 25 & 27 & 22 & 16 & 21 \\
\hline
\end{tabular}

521

522 Table 6 Average return temperatures to district heating for multi-storey building systems

\begin{tabular}{|c|c|c|c|c|c|c|}
\hline & \multicolumn{6}{|c|}{ Multi-storey building } \\
\hline & MTDH & & $\mathrm{LTDH}$ & & & ULTDH \\
\hline & $\begin{array}{l}\text { With tank } \\
\text { and } \\
\text { circulation }\end{array}$ & $\begin{array}{l}\text { IHEU } \\
\text { with } \\
\text { bypass }\end{array}$ & $\begin{array}{l}\text { Central HEX } \\
\text { with heat } \\
\text { pump }\end{array}$ & $\begin{array}{l}\text { IHEU with } \\
\text { bathroom } \\
\text { heating }\end{array}$ & $\begin{array}{l}\text { El- } \\
\text { tracing }\end{array}$ & $\begin{array}{l}\text { Micro } \\
\text { tank }\end{array}$ \\
\hline \multicolumn{7}{|l|}{ Average return } \\
\hline temperature $\left[{ }^{\circ} \mathrm{C}\right]$ & 28 & 24 & 20 & 23 & 19 & 16 \\
\hline
\end{tabular}

523

524 For the IHEU system supplied with LTDH, if the bypass is retained, the calculated return

525 temperatures to $\mathrm{DH}$ were $31^{\circ} \mathrm{C}$ for single-family houses and $26^{\circ} \mathrm{C}$ for multi-storey 
526 buildings based on the information in Table 4. However, as the bathroom heating is

527 applied, the average return temperature can be reduced to $22^{\circ} \mathrm{C}$ and $23^{\circ} \mathrm{C}$ instead. The

528 electric heat tracing and micro tank systems provided lower return temperatures to

529 district heating since no bypass or hot water circulation was operated for those systems.

530 The energy performances of the investigated systems are shown in the Fig. 8.

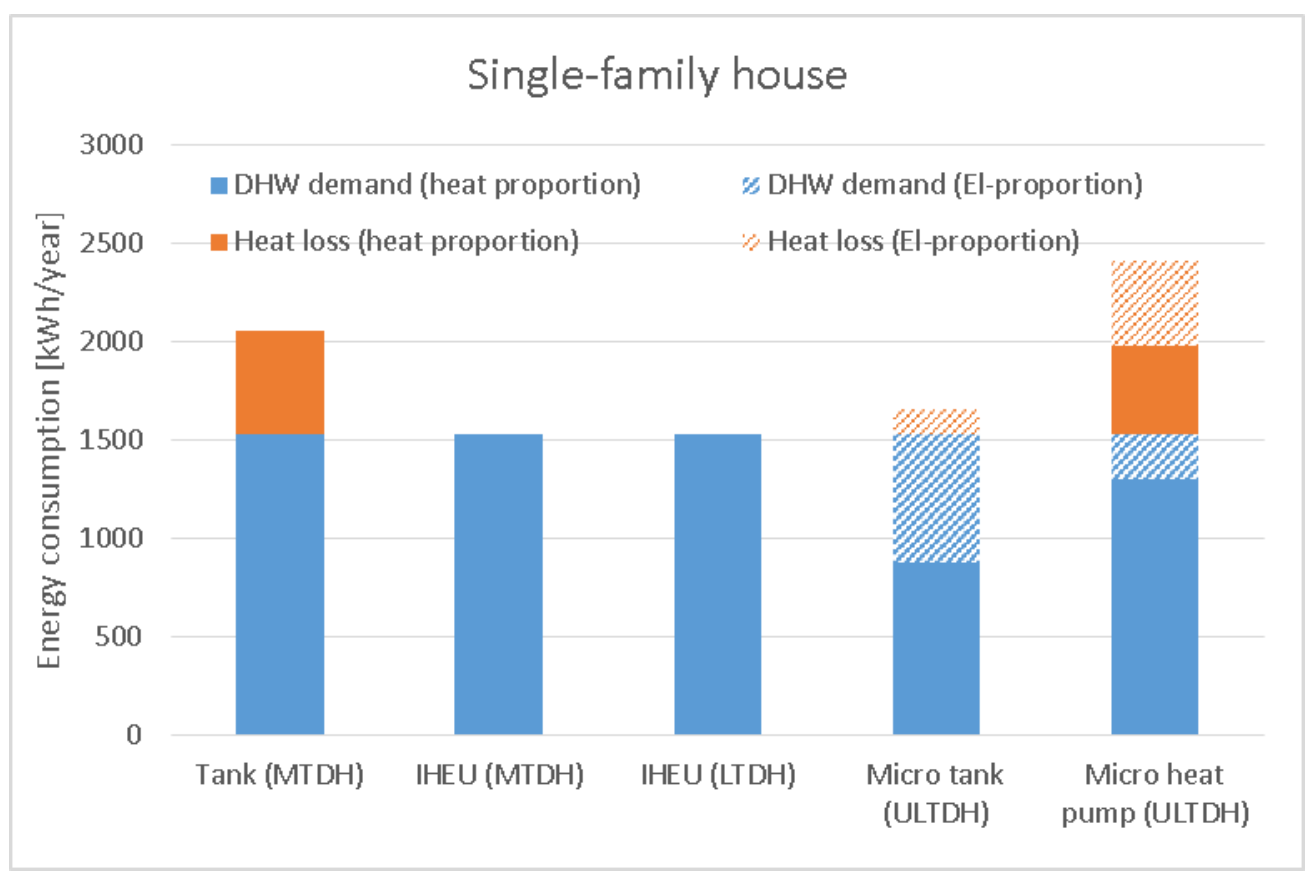




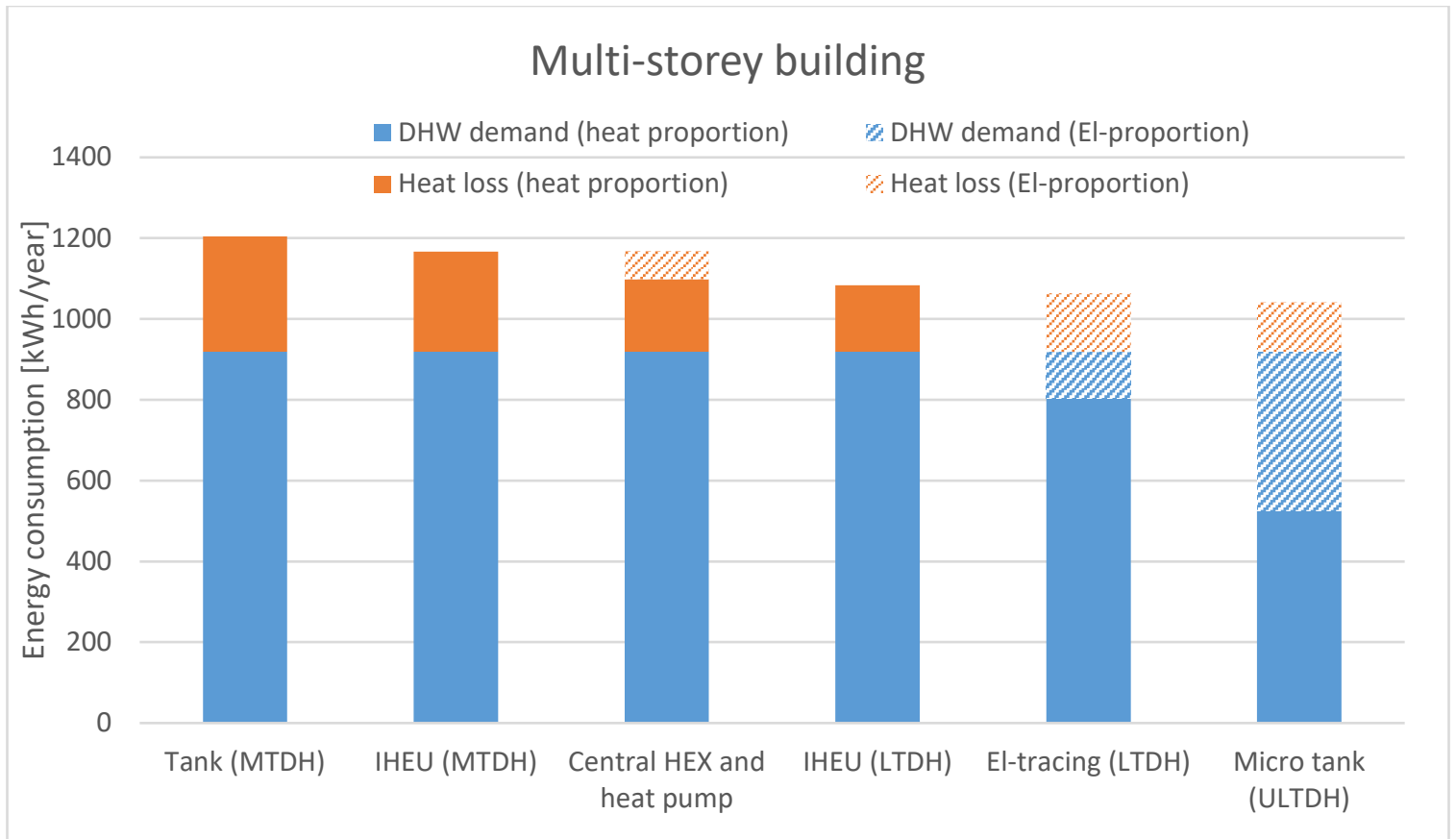

(b)

Fig. 8 Energy consumption in the different scenarios for DHW supply [kWh/year]

536 From the results, the systems with MTDH supply are all able to provide DHW demand

537 using just DH heat. The IHEU system requires less $\mathrm{DH}$ heat than the system with central

538 storage tank. In the LTDH scenario, IHEU system and electric heat tracing system

539 required less overall energy for DHW preparation. However, the electric heating tracing

540 system requires more electricity for supplementary heating and covering the heat loss.

541 Considering the different primary energy factors of heat and electricity, the IHEU

542 method might be the best solution for the LTDH scenario, since it generated less heat

543 loss than other methods and consumed no electricity. For the ULTDH scenario, the

544 micro tank system had much less heat loss compared with the micro heat pump system. 
5453.2 Results of the economic performance evaluation

546 The results of the annual energy costs and savings from lower return temperatures in

547 different scenarios can be found in Table 7 and Table 8.

548 Table 7 Evaluation of energy costs for single-family house systems

\begin{tabular}{llllll}
\hline & & & \multicolumn{3}{c}{ Single family house } \\
& MTDH & & LTDH & ULTDH & \\
& With tank & IHEU & IHEU & Micro tank & Micro heat \\
& & & & & pump \\
\hline $\begin{array}{l}\text { Heat cost [€/year] } \\
\text { Electricity cost [€/year] }\end{array}$ & 0 & 153 & 153 & 88 & 174 \\
$\begin{array}{l}\text { Energy cost [€/year] } \\
\text { Savings for DH system }\end{array}$ & 206 & 153 & 153 & 283 & 340 \\
[€/year] & 4.9 & 3.2 & 4.4 & 3.4 & 5.3 \\
\hline
\end{tabular}

549

550 Table 8 Evaluation of energy costs for multi-storey building

\begin{tabular}{|c|c|c|c|c|c|c|}
\hline & \multicolumn{6}{|c|}{ Multi-storey building } \\
\hline & MTDH & & LTDH & & & ULTDH \\
\hline & $\begin{array}{l}\text { With tank } \\
\text { and } \\
\text { circulation }\end{array}$ & IHEU & $\begin{array}{l}\text { Main HEX } \\
\text { with heat } \\
\text { pump }\end{array}$ & IHEU & $\begin{array}{l}\text { El- } \\
\text { tracing }\end{array}$ & $\begin{array}{l}\text { Micro } \\
\text { tank }\end{array}$ \\
\hline Heat cost [€/year] & 120 & 117 & 110 & 108 & 80 & 53 \\
\hline Electricity cost [€/year] & 0 & 0 & 18 & 0 & 65 & 129 \\
\hline Energy cost [€/year] & 120 & 117 & 128 & 108 & 145 & 182 \\
\hline $\begin{array}{l}\text { Savings for DH system } \\
\text { [€/year] }\end{array}$ & 2.3 & 3.0 & 3.7 & 2.9 & 2.7 & 2.0 \\
\hline
\end{tabular}

551

552 In the MTDH and LTDH scenarios, the energy cost of the IHEU system was less than the

553 other systems. The main reason was that the instantaneous DHW production by the 
554 IHEU eliminated the high temperature regime needed to meet the hygiene requirement,

555 thereby reducing the heat loss from the system, and no supplementary heating was

556 required. In a multi-storey building where substantial renovation is not feasible, the

557 system with a central heat exchanger and a heat pump had lower energy costs. In the

558 ULTDH scenario, where supplementary heating is necessary for DHW production, the

559 energy cost is much higher due to the electricity consumption. Here, the micro tank

560 system is more economical to apply than the micro heat pump system.

561 Since the saving potential from lower return temperatures for DH system is also

562 affected by total DH heat required for DHW supply, a system that requires more energy

563 for DHW production might have a large potential for savings. This means that the

564 solutions with supplementary heating might have a smaller potential for savings

565 because part of the energy supply is covered by electricity. Moreover, to investigate the

566 total savings from lower return temperatures, the role played by space heating should

567 be included, and the overall benefits would be more significant.

5683.3 Results of the exergy performance evaluation

569 The exergy performances of different scenarios are shown in Table 9 and Table 10.

570 Table 9 Results of the exergy evaluation model for the single-family house

\begin{tabular}{llllll}
\hline & & \multicolumn{5}{l}{ Single-family house } \\
& MTDH & & LTDH & ULTDH & \\
& With tank & IHEU & IHEU & Micro tank & Micro heat pump \\
\hline Ex_in [kWh] & 239 & 185 & 138 & 831 & 783 \\
Ex_out [kWh] & 99 & 99 & 99 & 99 & 99 \\
Efficiency [\%] & $41.6 \%$ & $54.3 \%$ & $71.3 \%$ & $12.0 \%$ & $12.7 \%$ \\
\hline
\end{tabular}


572 Table 10 Results of the exergy evaluation model for the multi-storey building

\begin{tabular}{|c|c|c|c|c|c|c|}
\hline & \multicolumn{6}{|c|}{ Multi-storey building } \\
\hline & MTDH & & LTDH & & & ULTDH \\
\hline & $\begin{array}{l}\text { With tank } \\
\text { and } \\
\text { circulation }\end{array}$ & IHEU & $\begin{array}{l}\text { Main HEX } \\
\text { with heat } \\
\text { pump }\end{array}$ & IHEU & El-tracing & $\begin{array}{l}\text { Micro } \\
\text { tank }\end{array}$ \\
\hline Ex_in [kWh] & 145 & 136 & 166 & 101 & 328 & 548 \\
\hline Ex_out [kWh] & 60 & 60 & 60 & 60 & 60 & 60 \\
\hline Efficiency [\%] & $41.1 \%$ & $44.7 \%$ & $35.8 \%$ & $59.7 \%$ & $18.1 \%$ & $10.9 \%$ \\
\hline
\end{tabular}

573

574 For both MTDH and LTDH, the IHEU system has higher exergy efficiency. While the

575 systems that require supplementary heating had lower exergy efficiency since extra

576 electricity with high exergy quality was consumed.

\section{4. Discussion}

578 In Denmark, the DH system is currently going through the transition from MTDH to

579 LTDH. The evaluation of the suitable substations corresponding to specific situations is

580 of great importance if LTDH is to be realized. In general, the decentralized approaches

581 for DHW supply performed better than the centralized approaches. In multi-storey

582 buildings, the decentralized system helps to reduce the total DHW volume of each

583 home, thereby eliminating the risk of Legionella. Moreover, the decentralized systems

584 can produce the DHW instantaneously in each home, so that thermal storage or DHW

585 circulation is unnecessary. As a result, the heat loss from the equipment can be much

586 reduced. 
587 Therefore, a decentralized IHEU system is a good solution for the realization of LTDH.

588 However, the operation of a bypass weakens the performance of IHEU systems by

589 increasing the return temperature to district heating. To reduce this negative impact,

590 one solution is to supply bathroom heating all year round. This heating flow can help to

591 keep the supply line warm, and ensure the 10s waiting time for comfort. To apply this

592 alternative method, one thing that should be noted is that the flow for bathroom

593 heating must be sufficient to maintain the set-point temperature for the most remote

594 consumer. The space heating demand of the bathroom which determines the bathroom

595 heating flow was calculated with a simplified method. However, for practical cases,

596 more factors should be taken into account for the calculation, such as the heat transfer

597 to the environment and neighbour rooms. Moreover, whether the benefits of the

598 reduced return temperature can balance the extra investment or the increased space-

599 heating demand in the bathroom requires detailed analysis in the specific case.

600 The economic evaluation in this study only included the energy cost. However, the full

601 picture can be obtained only if the investment and the operation and maintenance costs

602 are also included. The investment costs vary from case to case. The operation and

603 maintenance costs are greatly affected by the cost of labour, which can also be different

604 from case to case. Nevertheless, the results of this study can be helpful in the situation

605 where the decision has to be made among candidate solutions with known investment

606 prices. Policy makers can then derive the optimal solution by considering both factors

607 together. 
608 As one important factor, the LTDH can only be implemented if the return temperature

609 to district heating can be cooled down sufficiently. Therefore, encouragement is given

610 to the implementation of solutions with lower return temperatures. In Denmark, for

611 example, for every $1{ }^{\circ} \mathrm{C}$ the return temperature is below $42.9^{\circ} \mathrm{C}$, the $\mathrm{DH}$ company can

612 get $0.73 \mathrm{kr} / \mathrm{GJ}$ subsidy. In this study, the return temperature to district heating

613 calculated were based on standard operation, but the heat exchangers were specially

614 designed for LTDH, so the calculated return temperatures might be lower than in

615 practice. The operation of the storage tank was assumed to be ideal, which also results

616 in lower return temperature than in practice. However, with optimized design and

617 operation, low return temperatures similar to those calculated can be achieved.

\section{5. Conclusion}

619 The concern of Legionella growth and less comfort of the DHW supply restricts the

620 implementation of low-temperature district heating. This study analysed 11 different

621 scenarios for DHW production with MTDH, LTDH and ULTDH for single-family house and

622 multi-storey building. To meet the comfort and hygiene requirements, improvements or

623 innovative design were made for the DHW supply method with LTDH and ULTDH.

624 Energy, economy and exergy evaluation models were built to investigate the

625 performances of the proposed systems. The potential benefit by lower return

626 temperature was investigated. Recommended solutions to specific DH scenarios were

627 derived based on the results of the evaluations. 
628 For the MTDH scenario with supply temperature at $65^{\circ} \mathrm{C}$, the IHEU system has better

629 energy performance compared to the system with a storage tank in both single-family

630 houses and multi-storey buildings, since the instantaneous DHW preparation saves large

631 amount of heat loss caused by the storage tank. For the LTDH scenario, by redirecting

632 the bypass flow to floor heating in the bathroom, the return temperature of the IHEU

633 system achieves significant reduction. Being applied in multi-storey buildings, the

634 improved IHEU system requires the least primary energy for supplying the equivalent

635 DHW demand. While the system with the central heat exchanger combined with a heat

636 pump and the system with electric heating cables both require electricity for

637 supplementary heating, which increase the overall primary energy consumption. As a

638 result, the improved IHEU system also has better economy performance and higher

639 exergy efficiency. For the ULTDH scenario, the micro tank solution proposed consumes

640 less energy and is more economical than the micro heat pump solution, but has lower

641 exergy efficiency.

\section{Acknowledgement}

643 The work presented in this paper is a result of the research activities of the Strategic

644 Research Centre for $4^{\text {th }}$ Generation District Heating (4DH), which has received funding

645 from the Innovation Fund Denmark.

\section{References}

647 [1] Lund H, Werner S, Wiltshire R, Svendsen S, Thorsen JE, Hvelplund F, et al. 4th Generation 648 District Heating (4GDH) Integrating smart thermal grids into future sustainable energy systems. 649 Energy. 2014;68:1-11. 
[2] Thellufsen JZ, Lund H. Energy saving synergies in national energy systems. Energy Conversion 651 and Management. 2015;103:259-65.

652 [3] Bøhm B, Schrøder F, Bergsøe NC. Varmt Brugsvand: Måling af forbrug og varmetab fra 653 cirkulationsledninger [Domestic hot water: Measurement of consumption and heat loss from 654 circulation pipes] (in Danish). SBi 2009:10. Hørsholm, Denmark 2009. [4] DS/CEN/TR16355. Recommendations for prevention of Legionella growth in installations inside buildings conveying water for human consumption. Danish Standards; 2012. systems commonly used in the residential sector. Energy and Buildings. 2011;43(9):2140-4. [6] Thorsen JE. Analysis on flat station concept. The 12th international symposium on district heating and cooling. Tallinn, Estonia, 2010.

[7] Tol HI, Svendsen S. A comparative study on substation types and network layouts in connection with low-energy district heating systems. Energy Conversion and Management. 2012;64:551-61. external domestic hot water production system using four control strategies. Applied Energy. 2013;103:85-96.

[9] Chaturvedi SK, Gagrani VD, Abdel-Salam TM. Solar-assisted heat pump - A sustainable system for low-temperature water heating applications. Energy Conversion and Management. 2014;77:550-7.

[10] Brum M, Erickson P, Jenkins B, Kornbluth K. A comparative study of district and individual energy systems providing electrical-based heating, cooling, and domestic hot water to a lowenergy use residential community. Energy and Buildings. 2015;92:306-12.

[11] Bøhm B. Production and distribution of domestic hot water in selected Danish apartment buildings and institutions. Analysis of consumption, energy efficiency and the significance for energy design requirements of buildings. Energy Conversion and Management. 2013;67:152-9. [12] Yang X, Li H, Svendsen S. Modelling and multi-scenario analysis for electric heat tracing system combined with low temperature district heating for domestic hot water supply. Building simulation. 2016;9(2):141-51.

[13] Ghoubali R, Byrne P, Miriel J, Bazantay F. Simulation study of a heat pump for simultaneous heating and cooling coupled to buildings. Energy and Buildings. 2014;72:141-9.

[14] Elmegaard B, Ommen TS, Markussen M, Iversen J. Integration of space heating and hot water supply in low temperature district heating. Energy Buildings 2015.

[15] Boait PJ, Dixon D, Fan D, Stafford A. Production efficiency of hot water for domestic use. Energy and Buildings. 2012;54:160-8.

[16] Lu S, Wu JY. Optimal selection among different domestic energy consumption patterns based on energy and exergy analysis. Energy Conversion and Management. 2010;51(7):1398406.

[17] DS 439:2009. Norm for vandinstallationer [Code of practice for domestic water supply installations] (in Danish). Danish Standards; 2009.

[18] Danish Building Regulations (BR10). Danish Enterprise and Construction Authority; 2010. [19] Danfoss Redan A/S. Global Price List - District Energy Light Duty Stations. January 2014. [20] Brand M, Thorsen JE, Svendsen S. Numerical modelling and experimental measurements for a low-temperature district heating substation for instantaneous preparation of DHW with respect to service pipes. Energy. 2012;41(1):392-400.

[21] DS 452:2013. Termisk isolering af tekniske installationer [Thermal insulation of technical service and supply systems] (in Danish). Danish Standards; 2013.

[22] Svend F, Sven W. District heating and cooling. Sweden: Studentlitteratur, 2013. 
698 [23] Danfoss Redan A/S. Akva LES II VXi - Fully insulated district heating unit for future district 699 heating. 2015.

700 [24] Benchmarking 2015. Dansk Fjernvarme, [cited 2016 Feb 17]. Available from:

701 http://www.danskfjernvarme.dk/viden-om/aarsstatistik/benchmarking-statistik-2014-2015

702 [25] Electricity prices for domestic consumers - bi-annual data (from 2007 onwards). Eurostat,

703 [cited 2016 Feb 17]. Available from: http://ec.europa.eu/eurostat/en/web/products-datasets/-

704 /NRG_PC_204.

705 [26] Bejan A, Tsatsaronis G, Moran M. Thermal Design and Optimization, JohnWiley \& Sons, 7061996. 